\title{
Chalcogenoether complexes of tantalum(V) sulfide trichloride - synthesis, properties and structures
}

\author{
Robert D. Bannister, Willian Levason, Gillian Reid and Fred Robinson \\ School of Chemistry, University of Southampton, Highfield, Southampton, SO17 1BJ, UK. Email: \\ G.Reid@soton.ac.uk
}

\begin{abstract}
The complexes $\left[\mathrm{TaSCl}_{3}(\mathrm{~L}-\mathrm{L})\right]$ (L-L $=\mathrm{MeSCH}_{2} \mathrm{CH}_{2} \mathrm{SMe},{ }^{i} \mathrm{PrSCH}_{2} \mathrm{CH}_{2} \mathrm{~S}^{i} \mathrm{Pr}$, $\mathrm{PhSCH}_{2} \mathrm{CH}_{2} \mathrm{SPh}$, ${ }^{n} \mathrm{BuSCH}_{2} \mathrm{CH}_{2} \mathrm{CH}_{2} \mathrm{~S}^{\mathrm{n}} \mathrm{Bu}$, MeSCH${ }_{2} \mathrm{CH}_{2} \mathrm{CH}_{2} \mathrm{SMe}, \mathrm{MeSeCH} \mathrm{CH}_{2} \mathrm{SeMe}{ }^{\mathrm{n}} \mathrm{BuSeCH}_{2} \mathrm{CH}_{2} \mathrm{CH}_{2} \mathrm{Se}{ }^{n} \mathrm{Bu}$ ) have been synthesised and isolated in good yield as powdered solids by the reaction of $\mathrm{TaCl}_{5}$ with the appropriate chalcogenoether in a 1:1 molar ratio in anhydrous $\mathrm{CH}_{2} \mathrm{Cl}_{2}$ solution at room temperature, followed by the addition of a $\mathrm{CH}_{2} \mathrm{Cl}_{2}$ solution containing one mol. equiv. of $\mathrm{S}\left(\mathrm{SiMe}_{3}\right)_{2}$. The isolated complexes were characterised by $I R,{ }^{1} \mathrm{H}$ and ${ }^{77} \mathrm{Se}\left\{{ }^{1} \mathrm{H}\right\}$ NMR spectroscopy, as appropriate, and elemental analysis. Single crystal X-ray structure analyses for $\left[\mathrm{TaSCl}_{3}\left(\mathrm{MeSCH}_{2} \mathrm{CH}_{2} \mathrm{SMe}\right)\right], \quad\left[\mathrm{TaSCl}_{3}\left(\mathrm{MeSeCH}_{2} \mathrm{CH}_{2} \mathrm{SeMe}\right)\right], \quad\left[\mathrm{TaSCl}_{3}\left({ }^{(} \mathrm{PrSCH}_{2} \mathrm{CH}_{2} \mathrm{~S} \mathrm{Pr}\right)\right]$ and $\left[\mathrm{TaSCl}_{3}\left({ }^{\mathrm{n}} \mathrm{BuSCH}_{2} \mathrm{CH}_{2} \mathrm{CH}_{2} \mathrm{~S}^{\mathrm{n}} \mathrm{Bu}\right)\right]$ have been obtained. The data are compared with the previously described $\mathrm{Nb}(\mathrm{V})$ analogues. In contrast to the corresponding $\left[\mathrm{NbSCl}_{3}\left(\mathrm{E}^{\mathrm{n} B \mathrm{Bu}_{2}}\right)\right](\mathrm{E}=\mathrm{S}, \mathrm{Se})$, attempts to isolate $\left[\mathrm{TaSCl}_{3}\left(\mathrm{E}^{\mathrm{n} B u_{2}}\right)\right]$ were unsuccessful. Low pressure chemical vapour deposition (LPCVD) experiments using $\left[\mathrm{TaSCl}_{3}\left({ }^{n} \mathrm{BuSCH}_{2} \mathrm{CH}_{2} \mathrm{CH}_{2} \mathrm{~S}^{n} \mathrm{Bu}\right)\right]$ did not lead to any deposition, whilst similar experiments using $\left[\mathrm{TaSCl}_{3}\left({ }^{n} \mathrm{BuSeCH}_{2} \mathrm{CH}_{2} \mathrm{CH}_{2} \mathrm{Se}^{n} \mathrm{Bu}\right)\right]$ produced only elemental Se films, with no evidence for any deposition of tantalum sulfide or selenide films.
\end{abstract}

Keywords: tantalum sulfide trichloride, thioether, selenoether, crystal structure

\section{Introduction}

The early $4 d$ and $5 d$ metals in their higher oxidation states form sulfide and selenide halides which are modest Lewis acids, forming complexes with neutral ligands from groups 15 and 16, although they have received much less study than the corresponding oxide halides $[1,2,3]$. The $\operatorname{TaECl}_{3}(\mathrm{E}=$ $\mathrm{S}$, Se) were first obtained some 50 years ago by reaction of $\mathrm{TaCl}_{5}$ with $\mathrm{Sb}_{2} \mathrm{E}_{3}$ or $\mathrm{Bi}_{2} \mathrm{E}_{3}$ in $\mathrm{CS}_{2}[3,4]$ but in marked contrast to the $\mathrm{NbECl}_{3}[5,6,7,8]$, have been little studied, and the structures of the 
$\mathrm{TaECl}_{3}$ species appear to be unknown. A very small number of complexes of $\mathrm{TaECl}_{3}$ have been described, including [ $\left.\mathrm{TaSCl}_{3}(\mathrm{MeCN})_{2}\right][4,6],\left[\mathrm{TaSCl}_{3}\left(\mathrm{SMe}_{2}\right)_{2}\right]$ [4], [ $\left.\mathrm{TaSCl}_{3}\left\{\mathrm{PhS}\left(\mathrm{CH}_{2}\right)_{2} \mathrm{SPh}\right\}\right]$ [4] and the anions $\left[\mathrm{TaSCl}_{4}\left(\mathrm{~K}^{1}-1,4-\text { dioxane }\right)\right]^{-}$and $\left[\left(\mathrm{TaSCl}_{4}\right)_{2}(\mu-1,4-\text { dioxane })\right]^{2-}[9]$ of which the last three were authenticated by X-ray crystallographic studies. We have recently reported a comparison of the complexes of $\mathrm{TaOCl}_{3}$ and $\mathrm{TaSCl}_{3}$ with hard $\mathrm{O}$ - and $\mathrm{N}$-donor ligands, including the white $\left[\mathrm{TaOCl}_{3}\left(\mathrm{OPPh}_{3}\right)_{2}\right],\left[\mathrm{TaOCl}_{3}(\mathrm{~L}-\mathrm{L})\right]$ (L-L = 1,10-phenanthroline, 2,2'-bipyridyl, $\mathrm{Ph}_{2} \mathrm{P}(\mathrm{O}) \mathrm{CH}_{2} \mathrm{P}(\mathrm{O}) \mathrm{Ph}_{2}$, $\mathrm{Ph}_{2} \mathrm{P}(\mathrm{O}) \mathrm{CH}_{2} \mathrm{CH}_{2} \mathrm{P}(\mathrm{O}) \mathrm{Ph}_{2}$ and $\left.o-\mathrm{C}_{6} \mathrm{H}_{4}\left(\mathrm{P}(\mathrm{O}) \mathrm{Ph}_{2}\right)_{2}\right)$, which were prepared from $\mathrm{TaCl}_{5}, \mathrm{O}\left(\mathrm{SiMe}_{3}\right)_{2}$ and the ligands in anhydrous $\mathrm{CH}_{2} \mathrm{Cl}_{2}$ solution; the yellow $\left[\mathrm{TaSCl}_{3}\left(\mathrm{OPPh}_{3}\right)_{2}\right]$ and $\left[\mathrm{TaSCl}_{3}(\mathrm{~L}-\mathrm{L})\right]$ made similarly using $\mathrm{S}\left(\mathrm{SiMe}_{3}\right)_{2}$ [10]. X-ray crystal structures were obtained for [ $\mathrm{TaSCl}_{3}(1,10-$ phen)], $\left[\mathrm{TaSCl}_{3}\left(\mathrm{OPPh}_{3}\right)_{2}\right], \quad\left[\mathrm{TaSCl}_{3}\left\{\mathrm{Ph}_{2} \mathrm{P}(\mathrm{O}) \mathrm{CH}_{2} \mathrm{CH}_{2} \mathrm{P}(\mathrm{O}) \mathrm{Ph}_{2}\right\}\right]$ and $\left[\mathrm{TaSCl}_{3}(\mathrm{MeCN})_{2}\right]$, which all contain merchlorines, with the neutral ligands trans to $\mathrm{S} / \mathrm{Cl}$.

Layered transition metal dichalcogenides $\mathrm{ME}_{2}(\mathrm{M}=\mathrm{Nb}, \mathrm{Ta}, \mathrm{V}, \mathrm{W}$, Mo etc; $\mathrm{E}=\mathrm{S}$, Se or Te $)$ are inorganic analogues of graphene and their band gaps and other properties for various applications can be tuned by varying the chalcogen or the metal [11],[12]. In recent studies we have examined a range of thio- and seleno-ether complexes of niobium and tantalum halides as potential single source low pressure chemical vapour deposition (LPCVD) reagents for the production of thin films of the transition metal dichalcogenides [13-15]. Thus, $\left[\mathrm{NbCl}_{5}\left(\mathrm{E}^{\mathrm{n}} \mathrm{Bu}_{2}\right)\right]$ produced thin films of the 3R-polytype (R3mh) of $\mathrm{NbS}_{2}$ and $\mathrm{NbSe}_{2}$; the butyl-substituents provide a $\beta$-hydride decomposition route facilitating cleavage of the ligands in an accessible temperature range. Similar LPCVD experiments using the niobium sulfide trichloride complexes, $\left[\mathrm{NbSCl}_{3}\left(\mathrm{~S}^{n} \mathrm{Bu}_{2}\right)\right.$ and $\left[\mathrm{NbSCl}_{3}\left\{{ }^{\mathrm{n} B u S}\left(\mathrm{CH}_{2}\right)_{3} \mathrm{~S}^{\mathrm{n}} \mathrm{Bu}\right\}\right]$, produced $3 \mathrm{R}-\mathrm{NbS}_{2}$, whilst $\left[\mathrm{NbSe}_{2} \mathrm{Cl}_{3}\left(\mathrm{Se}^{\mathrm{n}} \mathrm{Bu}_{2}\right)\right]$ produced $2 \mathrm{H}-\mathrm{NbSe}_{2}$ thin films [8]. On the other hand, none of the corresponding tantalum complexes were found to be suitable LPCVD reagents, and single source precursors to $\mathrm{TaE}_{2}$ remain to be developed. Here we report the synthesis, spectroscopic and structural characterization of a series of complexes of $\mathrm{TaSCl}_{3}$ with thio- and seleno-ethers, along with the results from LPCVD experiments using selected examples.

\section{Experimental}

Infrared spectra were recorded as Nujol mulls between Csl plates using a Perkin-Elmer Spectrum 100 spectrometer over the range $4000-200 \mathrm{~cm}^{-1} .{ }^{1} \mathrm{H}$ and ${ }^{77} \mathrm{Se}\left\{{ }^{1} \mathrm{H}\right\}$ NMR spectra were recorded from $\mathrm{CD}_{2} \mathrm{Cl}_{2}$ solutions using a Bruker $\mathrm{AV} 400$ spectrometer and referenced to TMS via the residual solvent resonance and external neat $\mathrm{SeMe}_{2}$, respectively. Microanalyses were undertaken at 
Medac. Hexane was dried by distillation from sodium prior to use, and $\mathrm{CH}_{2} \mathrm{Cl}_{2}$ by distillation from $\mathrm{CaH}_{2}$. All preparations were carried out under rigorously anhydrous conditions via a dry dinitrogen atmosphere and standard Schlenk and glovebox techniques. $\mathrm{TaCl}_{5}$ and $\mathrm{S}\left(\mathrm{Me}_{3} \mathrm{Si}\right)_{2}$ were obtained from Sigma-Aldrich and used as received. The thioether and selenoether ligands were made as described $[16,17,18.19]$.

\section{$2.1\left[\mathrm{TaSCl}_{3}\left(\mathrm{PhSCH}_{2} \mathrm{CH}_{2} \mathrm{SPh}\right)\right] \cdot \mathrm{CH}_{2} \mathrm{Cl}_{2}$}

$\mathrm{TaCl}_{5}(0.30 \mathrm{~g}, 0.84 \mathrm{mmol})$ was stirred in dichloromethane $(5 \mathrm{~mL})$. A solution of $\mathrm{PhSCH}_{2} \mathrm{CH}_{2} \mathrm{SPh}(0.21$ $\mathrm{g}, 0.84 \mathrm{mmol})$ in dichloromethane $(1 \mathrm{~mL})$ was added and stirred for $2 \mathrm{~h}$, causing a colour change to yellow. $\mathrm{S}\left(\mathrm{Me}_{3} \mathrm{Si}\right)_{2}(0.15 \mathrm{~g}, 0.84 \mathrm{mmol})$ dissolved in dichloromethane was then added to the reaction mixture and stirred for $2 \mathrm{~h}$, giving a dark orange solution. The solvent was removed in vacuo and the resulting orange-brown solid was washed with $\mathrm{n}$-hexane $(2 \mathrm{~mL})$. Yield: $0.28 \mathrm{~g}, 59 \%$. Required for $\mathrm{C}_{14} \mathrm{H}_{14} \mathrm{Cl}_{3} \mathrm{~S}_{3} \mathrm{Ta} \cdot \mathrm{CH}_{2} \mathrm{Cl}_{2}$ (650.7): $\mathrm{C}, 27.69 ; \mathrm{H}, 2.4$. Found: $\mathrm{C}, 27.78,2.30 \%$. ${ }^{1} \mathrm{H} \mathrm{NMR}$ $\left(\mathrm{CD}_{2} \mathrm{Cl}_{2}, 295 \mathrm{~K}\right): 3.84$ (br s, [4H], $\mathrm{CH}_{2}$ ), 7.37-7.50 (m, [10H], Ph); (203 K): 3.75 (br s, [2H], $\mathrm{CH}_{2}$ ), 4.09 (br s, [2H], CH $\mathrm{CH}_{2}$ ) 7.36-7.64 (m, [10H], Ph. IR spectrum (Nujol mull)/cm ${ }^{-1}$ : 519, 513 (Ta=S), 360s, $320 \mathrm{~m}(\mathrm{br}, \mathrm{Ta}-\mathrm{Cl})$.

\section{$2.2\left[\mathrm{TaSCl}_{3}\left(\mathrm{MeSCH}_{2} \mathrm{CH}_{2} \mathrm{SMe}\right)\right]$}

Method 1: $\mathrm{TaCl}_{5}(0.30 \mathrm{~g}, 0.84 \mathrm{mmol})$ was stirred in anhydrous $\mathrm{CH}_{2} \mathrm{Cl}_{2}(5 \mathrm{~mL})$. A solution of $\mathrm{MeSCH}_{2} \mathrm{CH}_{2} \mathrm{SMe}(0.11 \mathrm{~g}, 0.84 \mathrm{mmol})$ in $\mathrm{CH}_{2} \mathrm{Cl}_{2}(5 \mathrm{~mL})$ was added and the reaction stirred for 30 min., giving a yellow solution immediately on addition of the ligand. $\mathrm{S}\left(\mathrm{SiMe}_{3}\right)_{2}(0.15 \mathrm{~g}, 0.84 \mathrm{mmol})$ dissolved in $\mathrm{CH}_{2} \mathrm{Cl}_{2}(1 \mathrm{~mL})$, was then added to the reaction mixture, causing a colour change from bright yellow to straw coloured with some solid precipitating. The reaction was stirred for a further $16 \mathrm{~h}$, during which time the solid all dissolved and the solution became darker. The solution was filtered and then concentrated and a dark brown solid was precipitated with nhexane $(2 \mathrm{~mL})$, collected by filtration and dried in vacuo. Yield $0.24 \mathrm{~g}, 66 \%$. Orange crystals were obtained by layering a dichloromethane solution of the product with hexane. Required for $\mathrm{C}_{4} \mathrm{H}_{10} \mathrm{Cl}_{3} \mathrm{~S}_{3} \mathrm{Ta}$ (441.3): $\mathrm{C}, 10.88 ; \mathrm{H}, 2.28 \%$. Found: $\mathrm{C}, 11.23 ; \mathrm{H}, 2.65 \% .{ }^{1} \mathrm{H}$ NMR $\left(\mathrm{CD}_{2} \mathrm{Cl}_{2}, 295 \mathrm{~K}\right): 2.27$ (s, [3H], Me), 2.89 (s, [3H], Me), 3.08 (br m, [2H], $\mathrm{CH}_{2}$ ), 3.47 (br m, [2H], $\left.\mathrm{CH}_{2}\right) . \mathrm{IR}(\mathrm{Nujol}) / \mathrm{cm}^{-1}: 508$ $\mathrm{s}(\mathrm{Ta}=\mathrm{S}), 327 \mathrm{~m}, 352 \mathrm{~s}(\mathrm{Ta}-\mathrm{Cl})$.

\section{$2.3\left[\mathrm{TaSCl}_{3}\left({ }^{\mathrm{P} P S C \mathrm{CH}_{2}} \mathrm{CH}_{2} \mathrm{~S}^{\mathrm{i}} \mathrm{Pr}\right)\right]$}


$\mathrm{TaCl}_{5}\left(0.30 \mathrm{~g}, 0.837 \mathrm{mmol}\right.$ ) was stirred in $\mathrm{CH}_{2} \mathrm{Cl}_{2}(5 \mathrm{~mL})$. A solution of ${ }^{\mathrm{i}} \mathrm{PrSCH}_{2} \mathrm{CH}_{2} \mathrm{~S} \operatorname{Pr}(0.19 \mathrm{~g}, 0.84$ mmol) in $\mathrm{CH}_{2} \mathrm{Cl}_{2}(5 \mathrm{~mL})$ was added and stirred for $16 \mathrm{~h}$, giving a yellow solution. $\mathrm{S}\left(\mathrm{SiMe}_{3}\right)_{2}(0.15 \mathrm{~g}$, $0.84 \mathrm{mmol})$ dissolved in $\mathrm{CH}_{2} \mathrm{Cl}_{2}(1 \mathrm{~mL})$ was then added to the reaction mixture and stirred for 2 days, during which the solution turned from yellow to brown to black. The solution was concentrated and the dark solid was precipitated with $\mathrm{n}$-hexane, collected by filtration, washed with n-hexane and dried in vacuo. Yield $0.32 \mathrm{~g}, 77 \%$. Dark purple crystals were obtained by layering a solution of the product in $\mathrm{CH}_{2} \mathrm{Cl}_{2}$ with hexane. Required for $\mathrm{C}_{8} \mathrm{H}_{18} \mathrm{Cl}_{3} \mathrm{~S}_{3} \mathrm{Ta}$ (497.4): C, 19.30; $\mathrm{H}, 3.65$. Found: $\mathrm{C}, 18.73 ; \mathrm{H}, 3.50 \% .{ }^{1} \mathrm{H} \mathrm{NMR}\left(\mathrm{CD}_{2} \mathrm{Cl}_{2}, 295 \mathrm{~K}\right): \delta=1.34\left(\mathrm{~d},[6 \mathrm{H}],{ }^{3} \mathrm{~J}=8 \mathrm{~Hz}, \mathrm{CH}_{3}\right)$, $1.61\left(\mathrm{~d},[6 \mathrm{H}],{ }^{3} \mathrm{~J}=8 \mathrm{~Hz}, \mathrm{CH}_{3}\right), 3.05\left(\mathrm{~m},[2 \mathrm{H}], \mathrm{CH}_{2}\right), 3.24$ (septet, [1H], $\left.{ }^{3} \mathrm{~J}=8 \mathrm{~Hz}, \mathrm{CH}\right), 3.49(\mathrm{~m},[2 \mathrm{H}]$, $\mathrm{CH}_{2}$ ), 3.58 (septet $[1 \mathrm{H}],{ }^{3} \mathrm{~J}=8 \mathrm{~Hz}, \mathrm{CH}$ ). IR spectrum (Nujol)/cm ${ }^{-1}: 509$ (Ta=S), $329 \mathrm{~s}, 351 \mathrm{~m}(\mathrm{Ta}-\mathrm{Cl})$.

\section{$2.4\left[\mathrm{TaSCl}_{3}\left(\mathrm{MeSCH}_{2} \mathrm{CH}_{2} \mathrm{CH}_{2} \mathrm{SMe}\right)\right]$}

$\mathrm{TaCl}_{5}(0.30 \mathrm{~g}, 0.84 \mathrm{mmol})$ was stirred in $\mathrm{CH}_{2} \mathrm{Cl}_{2}(5 \mathrm{~mL})$. A solution of $\mathrm{MeSCH}_{2} \mathrm{CH}_{2} \mathrm{CH}_{2} \mathrm{SMe}(0.115 \mathrm{~g}$, $0.84 \mathrm{mmol})$ in $\mathrm{CH}_{2} \mathrm{Cl}_{2}(5 \mathrm{~mL})$ was added and stirred for $4 \mathrm{~h}$. The solution turned yellow on addition of the ligand. $\mathrm{S}\left(\mathrm{SiMe}_{3}\right)_{2}(0.149 \mathrm{~g}, 0.84 \mathrm{mmol})$ dissolved in $\mathrm{CH}_{2} \mathrm{Cl}_{2}(1 \mathrm{~mL})$ was then added to the reaction mixture and stirred for $16 \mathrm{~h}$. The solution turned from bright yellow to dark green. Dark green crystals were obtained from a $\mathrm{CH}_{2} \mathrm{Cl}_{2}$ solution of the product layered with hexane. Yield $0.243 \mathrm{~g}, 64$ \%. Required for $\mathrm{C}_{5} \mathrm{H}_{12} \mathrm{Cl}_{3} \mathrm{~S}_{3} \mathrm{Ta}$ (455.3): $\mathrm{C}, 13.18 ; \mathrm{H}, 2.65$. Found: $\mathrm{C}, 13.40 ; \mathrm{H}, 2.64 \%$ \%. ${ }^{1} \mathrm{H}$ NMR $\left(\mathrm{CD}_{2} \mathrm{Cl}_{2}, 295 \mathrm{~K}\right): \delta=2.08(\mathrm{br} \mathrm{s},[3 \mathrm{H}], \mathrm{Me}), 2.24$ (s, [3H], Me) 2.58 (br s, [2H], $\mathrm{CH}_{2}$ ), 3.01 (br s, [2H], $\mathrm{CH}_{2}$ ), 3.32 (br s, [2H], $\mathrm{CH}_{2}$ ). IR spectrum (Nujol)/cm ${ }^{-1}$ : $507 \mathrm{~m}$ (Ta=S), 326 br, s (Ta-Cl).

\section{$2.5\left[\mathrm{TaSCl}_{3}\left({ }^{n} \mathrm{BuSCH} \mathrm{CH}_{2} \mathrm{CH}_{2} \mathrm{~S}^{n} \mathrm{Bu}\right)\right]$}

$\mathrm{TaCl}_{5}(0.30 \mathrm{~g}, 0.84 \mathrm{mmol})$ was stirred in $\mathrm{CH}_{2} \mathrm{Cl}_{2}(5 \mathrm{~mL})$. A solution of ${ }^{n} \mathrm{BuSCH}_{2} \mathrm{CH}_{2} \mathrm{CH}_{2} \mathrm{~S}^{\mathrm{n} B u}(0.185 \mathrm{~g}$, $0.84 \mathrm{mmol})$ in $\mathrm{CH}_{2} \mathrm{Cl}_{2}(5 \mathrm{~mL})$ was added and stirred for $4 \mathrm{~h}$. The solution turned yellow after stirring for 20 mins. $\mathrm{S}\left(\mathrm{SiMe}_{3}\right)_{2}(0.15 \mathrm{~g}, 0.84 \mathrm{mmol})$, dissolved in $\mathrm{CH}_{2} \mathrm{Cl}_{2}(1 \mathrm{~mL})$ was then added to the reaction mixture and stirred for $16 \mathrm{~h}$; after 30 mins. the solution had turned from yellow to black. A dark solid was precipitated by the addition of $\mathrm{n}$-hexane, collected by filtration, washed with $\mathrm{n}$ hexane and dried in vacuo. Yield $0.211 \mathrm{~g}, 47$ \%. Required for $\mathrm{C}_{11} \mathrm{H}_{24} \mathrm{Cl}_{3} \mathrm{~S}_{3} \mathrm{Ta}$ (539.8): $\mathrm{C}, 24.47 ; \mathrm{H}$, 4.48. Found: $\mathrm{C}, 24.33 ; \mathrm{H}, 4.70 \% .{ }^{1} \mathrm{H}$ NMR $\left(\mathrm{CD}_{2} \mathrm{Cl}_{2}\right): 0.91\left(\mathrm{~m},[3 \mathrm{H}], \mathrm{CH}_{3}\right), 0.93\left(\mathrm{~m},[3 \mathrm{H}], \mathrm{CH}_{3}\right), 1.41$ (vbr, m, [6H], $\left.\mathrm{CH}_{2}\right), 1.55\left(\mathrm{br},[4 \mathrm{H}], \mathrm{CH}_{2}\right), 2.51\left(\mathrm{~m}[2 \mathrm{H}], \mathrm{CH}_{2}\right), 2.59\left(\mathrm{br},[2 \mathrm{H}], \mathrm{CH}_{2}\right), 3.07$ (v br [2H], $\mathrm{CH}_{2}$ ), 3.31 (v br [2H], $\mathrm{CH}_{2}$ ). IR spectrum (Nujol)/ $\mathrm{cm}^{-1}$ : 508 (Ta=S), 340sh, 328 (br, Ta-Cl).

\section{$2.6\left[\mathrm{TaSCl}_{3}\left(\mathrm{MeSeCH}_{2} \mathrm{CH}_{2} \mathrm{SeMe}\right)\right]$}


$\mathrm{TaCl}_{5}(0.30 \mathrm{~g}, 0.837 \mathrm{mmol})$ was stirred in $\mathrm{CH}_{2} \mathrm{Cl}_{2}(5 \mathrm{~mL})$. A solution of $\mathrm{MeSeCH}_{2} \mathrm{CH}_{2} \mathrm{SeMe}(0.181 \mathrm{~g}$, $0.837 \mathrm{mmol})$ in $\mathrm{CH}_{2} \mathrm{Cl}_{2}(5 \mathrm{~mL})$ was added and stirred for $3 \mathrm{~h}$, giving a yellow solution. $\mathrm{S}\left(\mathrm{SiMe}_{3}\right)_{2}$ ( $0.149 \mathrm{~g}, 0.84 \mathrm{mmol})$ dissolved in $\mathrm{CH}_{2} \mathrm{Cl}_{2}(1 \mathrm{~mL})$ was then added to the reaction mixture and stirred for $3 \mathrm{~h}$, causing a colour change to brown then black. The solution was concentrated and a black solid and dark purple crystals were formed by addition of a layer of $n$-hexane $(2 \mathrm{~mL})$. These were collected by filtration and dried in vacuo. Yield $0.37 \mathrm{~g}, 82 \%$. Required for $\mathrm{C}_{4} \mathrm{H}_{10} \mathrm{Cl}_{3} \mathrm{SSe}_{2} \mathrm{Ta} \mathrm{CH}_{2} \mathrm{Cl}_{2}$ (620.35): $\mathrm{C}, 9.68 ; \mathrm{H}, 1.95$. Found: $\mathrm{C}, 9.55 ; \mathrm{H}, 1.94 \% .{ }^{1} \mathrm{H} \mathrm{NMR}\left(\mathrm{CD}_{2} \mathrm{Cl}_{2}\right): \delta=2.15$ (s, [3H], Me), 2.74 (s, [3H], Me), 3.13 (br m, [2H], $\mathrm{CH}_{2}$ ), 3.63 (br m, [2H], $\left.\mathrm{CH}_{2}\right) .{ }^{77} \mathrm{Se}\left\{{ }^{1} \mathrm{H}\right\} \operatorname{NMR}\left(\mathrm{CD}_{2} \mathrm{Cl}_{2}, 295 \mathrm{~K}\right.$ ): 144 (s, [Se]), 186 (s,[Se]). IR spectrum (Nujol)/cm-1: 326 s, 348 m (Ta-Cl), 507 s (Ta=S).

\section{7 [ $\left.\mathrm{TaSCl}_{3}\left({ }^{n} \mathrm{BuSeCH} \mathrm{CH}_{2} \mathrm{CH}_{2} \mathrm{Se}{ }^{n} \mathrm{Bu}\right)\right]$}

$\mathrm{TaCl}_{5}(0.30 \mathrm{~g}, 0.84 \mathrm{mmol})$ was stirred in $\mathrm{CH}_{2} \mathrm{Cl}_{2}(5 \mathrm{~mL})$. A solution of ${ }^{\mathrm{n}} \mathrm{BuSeCH}_{2} \mathrm{CH}_{2} \mathrm{CH}_{2} \mathrm{Se}{ }^{\mathrm{n}} \mathrm{Bu}(0.26$ $\mathrm{g}, 0.84 \mathrm{mmol})$ in $\mathrm{CH}_{2} \mathrm{Cl}_{2}(5 \mathrm{~mL})$ was added and stirred for $4 \mathrm{~h}$. The solution turned yellow after 30 mins. $\mathrm{S}\left(\mathrm{SiMe}_{3}\right)_{2}(0.15 \mathrm{~g}, 0.84 \mathrm{mmol})$ dissolved in $\mathrm{CH}_{2} \mathrm{Cl}_{2}(1 \mathrm{~mL})$ was then added to the reaction mixture and stirred for $16 \mathrm{~h}$, during which the solution turned from yellow to black. The solvent was removed in vacuo leaving a dark oil, which was washed with hexane and afforded a black solid. Yield $0.28 \mathrm{~g}, 52 \%$. Required for $\mathrm{C}_{11} \mathrm{H}_{24} \mathrm{Cl}_{3} \mathrm{SSe}_{2} \mathrm{Ta} \mathrm{CH}_{2} \mathrm{Cl}_{2}$ (718.5): C, 20.06; H, 3.65. Found: C, 19.86; $\mathrm{H}, 3.67 \% .{ }^{1} \mathrm{H}$ NMR $\left(\mathrm{CD}_{2} \mathrm{Cl}_{2}, 295 \mathrm{~K}\right): \delta=0.93\left(\mathrm{t},[6 \mathrm{H}], \mathrm{CH}_{3}\right), 1.43\left(\mathrm{~m},[4 \mathrm{H}], \mathrm{CH}_{2}\right), 1.66(\mathrm{~m},[4 \mathrm{H}]$, $\left.\mathrm{CH}_{2}\right), 1.99\left(\mathrm{br},[2 \mathrm{H}], \mathrm{CH}_{2}\right), 2.34\left(\mathrm{br},[2 \mathrm{H}], \mathrm{CH}_{2}\right), 2.58\left(\mathrm{br},[2 \mathrm{H}], \mathrm{CH}_{2}\right), 2.62\left(\mathrm{br},[2 \mathrm{H}], \mathrm{CH}_{2}\right), 2.62(\mathrm{br}$, $[2 \mathrm{H}]), 3.19\left(\mathrm{br},[2 \mathrm{H}], \mathrm{CH}_{2}\right) .{ }^{77} \mathrm{Se}\left\{{ }^{1} \mathrm{H}\right\} \mathrm{NMR}\left(\mathrm{CH}_{2} \mathrm{Cl}_{2}, 298 \mathrm{~K}\right)$ : no resonance. IR spectrum (Nujol)/ $/ \mathrm{cm}^{-1}$ : 331, 307 (br, Ta-Cl), 508 (Ta=S).

\subsection{X-Ray experimental}

Data collections for single crystal X-ray analyses used a Rigaku AFC12 goniometer equipped with an enhanced sensitivity (HG) Saturn724+ detector mounted at the window of an FR-E+ SuperBright molybdenum $(\lambda=0.71073)$ rotating anode generator with VHF Varimax optics (70 micron focus) with the crystal held at $100 \mathrm{~K}$ ( $\mathrm{N}_{2}$ cryostream). Crystallographic parameters are in the (Table 1). Structure solution and refinement were performed using SHELX(S/L)97, SHELX2014/7 [20], H atoms were added and refined with a riding model.

\section{Results and Discussion}

Addition of the one mol. equivalent of the dithioethers $\mathrm{PhSCH}_{2} \mathrm{CH}_{2} \mathrm{SPh}$, $\mathrm{MeSCH}_{2} \mathrm{CH}_{2} \mathrm{SMe}$, MeSCH${ }_{2} \mathrm{CH}_{2} \mathrm{CH}_{2} \mathrm{SMe}^{\mathrm{n}} \mathrm{BuSCH}_{2} \mathrm{CH}_{2} \mathrm{CH}_{2} \mathrm{~S}^{\mathrm{n}} \mathrm{Bu}$ or ${ }^{\mathrm{P}} \mathrm{PrSCH}_{2} \mathrm{CH}_{2} \mathrm{~S}$ 'Pr to $\mathrm{TaCl}_{5}$ in anhydrous $\mathrm{CH}_{2} \mathrm{Cl}_{2}$ gave 
bright yellow solutions. Treatment of these solutions with one mol. equivalent of $\mathrm{S}\left(\mathrm{SiMe}_{3}\right)_{2}$ in $\mathrm{CH}_{2} \mathrm{Cl}_{2}$ caused the colours to darken and work up gave dark solids with microanalyses confirming the composition as $\left[\mathrm{TaSCl}_{3}\right.$ (dithioether)]. The colours of the solids isolated with a specific dithioether were observed to be rather variable although the IR and NMR spectra indicated all batches contained the same species. The solid complexes also darken and become sticky over time in the glove box. Similar colour variation has been observed in the $\mathrm{NbSCl}_{3}$ systems $[7,8,21]$ and was attributed to the presence of small amounts of disulfide $\left(\left[\mathrm{S}_{2}\right]^{2-}\right)$ ligands in some samples, formed by a redox-disproportionation reaction, and formation of complexes such as $\left[\mathrm{Nb}_{2} \mathrm{Cl}_{4} \mathrm{~S}_{3}(\mathrm{tht})_{4}\right]$ (tht = tetrahydrothiophene) [7]. Similar disulfide species have not been identified thus far in the tantalum thiochloride systems, but this appears a likely explanation for the colour variation in the complexes reported here. For several of the complexes the single crystals selected for the X-ray analysis were also intensely coloured, e.g. orange-brown for $\left[\mathrm{TaSCl}_{3}\left(\mathrm{MeSCH}_{2} \mathrm{CH}_{2} \mathrm{SMe}\right)\right]$, purple for $\left[\mathrm{TaSCl}_{3}\left({ }^{\mathrm{i}} \mathrm{PrSCH}_{2} \mathrm{CH}_{2} \mathrm{~S} \mathrm{P} \mathrm{Pr}\right)\right]$, dark green for $\left[\mathrm{TaSCl}_{3}\left(\mathrm{MeSCH}_{2} \mathrm{CH}_{2} \mathrm{CH}_{2} \mathrm{SMe}\right)\right]$. Attempts to prepare the complexes from [ $\mathrm{TaSCl}_{3}\left(\mathrm{MeCN}_{2}\right.$ ] [10] were not successful, with the MeCN not being cleanly substituted. The addition of the appropriate diselenoethers, $\mathrm{MeSeCH}{ }_{2} \mathrm{CH}_{2} \mathrm{SeMe}$ or ${ }^{n} \mathrm{BuSeCH}_{2} \mathrm{CH}_{2} \mathrm{CH}_{2} \mathrm{Se}^{n} \mathrm{Bu}$ to a solution of $\mathrm{TaCl}_{5}$ in $\mathrm{CH}_{2} \mathrm{Cl}_{2}$, followed by $\mathrm{S}\left(\mathrm{SiMe}_{3}\right)_{2}$, gave the purple-black $\left[\mathrm{TaSCl}_{3}\right.$ (diselenoether)], but attempts to isolate $\left[\mathrm{TaSCl}_{3}\left(\mathrm{MeSeCH}_{2} \mathrm{CH}_{2} \mathrm{CH}_{2} \mathrm{SeMe}\right)\right]$ were unsuccessful.

Crystals of $\left[\mathrm{TaSCl}_{3}\left({ }^{n} \mathrm{BuSCH}_{2} \mathrm{CH}_{2} \mathrm{CH}_{2} \mathrm{~S}^{n} \mathrm{Bu}\right)\right]$ were obtained from a $\mathrm{CH}_{2} \mathrm{Cl}_{2}$ solution layered with $n$ hexane. The structure is shown in Figure 1 and reveals six-coordinate tantalum with mer-chlorines and the dithioether, which has the meso-conformation, trans to $\mathrm{S} / \mathrm{Cl}$. The $\mathrm{d}(\mathrm{Ta}-\mathrm{S} 1)=2.199(3) \AA$ and $d(\mathrm{Ta}-\mathrm{Cl} 2)=2.283(3) \AA$, whilst the axial Ta-Cl are significantly longer ( $2.360(2), 2.345(2) \AA)$. Disorder of the $\mathrm{S}$ and $\mathrm{Cl}$ trans to the neutral ligands in complexes of the type $\left[\mathrm{MSCl}_{3}\left(\mathrm{~L}_{2}\right](\mathrm{M}=\mathrm{Nb}\right.$, $\mathrm{Ta}$ ) is common $[5,8,9,22]$, and since $\mathrm{S}^{2-}$ and $\mathrm{Cl}^{-}$are isoelectronic and have very similar scattering power, it is not possible to completely rule out some disorder in such systems. However, in the case of $\left[\mathrm{TaSCl}_{3}\left({ }^{\mathrm{n}} \mathrm{BuSCH}_{2} \mathrm{CH}_{2} \mathrm{CH}_{2} \mathrm{~S}^{n} \mathrm{Bu}\right)\right]$, the structure appears disorder-free, with the difference in $\mathrm{Ta}=\mathrm{S}$ and $\mathrm{Ta}-\mathrm{Cl} 2$ much as expected. It is notable that the Ta- $\mathrm{S}_{\text {thioether }}$ distances are also significantly different $d(T a 1-S 3)=2.684(2)$ and $d(T a 1-S 2)=2.791(2) \AA$, which is attributed to the trans influence $\mathrm{Ta}=\mathrm{S}>\mathrm{Ta}-\mathrm{Cl}$. The complex adopts the $\mathrm{DL}$ stereoisomer. 


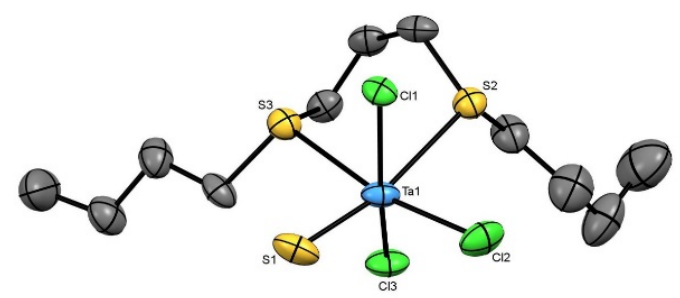

Figure 1 View of the structure of $\left[\mathrm{TaSCl}_{3}\left({ }^{\mathrm{n}} \mathrm{BuSCH}_{2} \mathrm{CH}_{2} \mathrm{CH}_{2} \mathrm{~S}^{\mathrm{n}} \mathrm{Bu}\right)\right]$ with numbering scheme adopted. Ellipsoids are shown at the $50 \%$ probability level and $\mathrm{H}$ atoms are omitted for clarity. Selected bond lengths $(\AA \AA)$ and angles $\left({ }^{\circ}\right): \mathrm{Ta} 1-\mathrm{Cl} 1=2.360(2), \mathrm{Ta} 1-\mathrm{S} 3=2.684(2), \mathrm{Ta} 1-\mathrm{Cl} 3=2.345(2), \mathrm{Ta} 1-\mathrm{S} 1$ $=2.199(3), \mathrm{Ta} 1-\mathrm{S} 2=2.791(2), \mathrm{Ta} 1-\mathrm{Cl} 2=2.283(3), \mathrm{Cl} 1-\mathrm{Ta} 1-\mathrm{S} 3=82.12(7), \mathrm{Cl} 1-\mathrm{Ta} 1-\mathrm{S} 2=75.16(7)$, $\mathrm{S} 3-\mathrm{Ta} 1-\mathrm{S} 2=80.59(7), \mathrm{Cl} 3-\mathrm{Ta} 1-\mathrm{Cl} 1=156.78(8), \mathrm{Cl} 3-\mathrm{Ta} 1-\mathrm{S} 3=82.87(8), \mathrm{Cl} 3-\mathrm{Ta} 1-\mathrm{S} 2=84.99(8)$, S1-Ta1-Cl1 = 97.24(8), S1-Ta1-S3 = 90.45(10), S1-Ta1-Cl3 = 100.49(9), S1-Ta1-S2 = 168.90(9), $\mathrm{S} 1-\mathrm{Ta} 1-\mathrm{Cl} 2=103.81(11), \mathrm{Cl} 2-\mathrm{Ta} 1-\mathrm{Cl} 1=95.64(9), \mathrm{Cl} 2-\mathrm{Ta} 1-\mathrm{S} 3=165.74(9), \mathrm{Cl} 2-\mathrm{Ta} 1-\mathrm{Cl} 3=$ 94.56(9), $\mathrm{Cl} 2-\mathrm{Ta} 1-\mathrm{S} 2=85.22(9)$.

X-ray structures were also determined for $\left[\mathrm{TaSCl}_{3}\left(\mathrm{MeSCH}_{2} \mathrm{CH}_{2} \mathrm{SMe}\right)\right]$ and $\left[\mathrm{TaSCl}_{3}\left({ }^{\mathrm{i}} \mathrm{PrSCH}_{2} \mathrm{CH}_{2} \mathrm{~S}^{\mathrm{i}} \mathrm{Pr}\right)\right]$ (Figures 2 and 3), and here the very similar " $\mathrm{Ta}=\mathrm{S}$ " and "Ta- $\mathrm{Cl}_{\text {transs" }}$ " and the similar Ta-S distances to the dithioether ligands clearly show that disorder is present. Attempts to model the disorder by splitting the site occupancies were unsuccessful, and whilst the structures serve to confirm the basic geometries, comparisons of the metrical data are unreliable. The coordinated dithioethers in both structures are the $D L$ diastereoisomer.

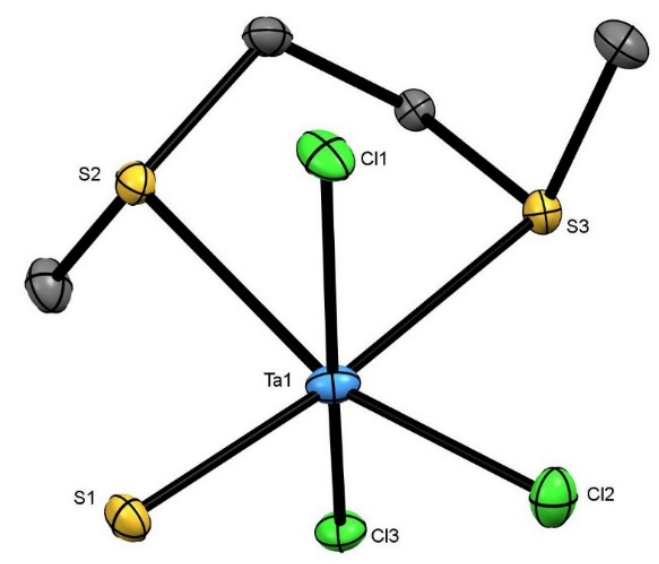

Figure 2 View of the structure of $\left[\mathrm{TaSCl}_{3}\left(\mathrm{MeSCH}_{2} \mathrm{CH}_{2} \mathrm{SMe}\right)\right]$ with numbering scheme adopted. Ellipsoids are shown at the $50 \%$ probability level. Note that $\mathrm{S} 1$ and $\mathrm{Cl} 2$ are disordered. Selected bond lengths $(\AA)$ and angles $\left({ }^{\circ}\right)$ : Ta1-S3 = 2.7243(13), Ta1-Cl3 = 2.3600(12), Ta1-S1 = 2.2301(13), $\mathrm{Ta} 1-\mathrm{Cl} 2=2.2642(13), \mathrm{Ta} 1-\mathrm{S} 2=2.6993(12), \mathrm{Ta} 1-\mathrm{Cl} 1=2.3522(13), \mathrm{Cl} 3-\mathrm{Ta} 1-\mathrm{S} 3=76.71(4)$, $\mathrm{Cl} 3-\mathrm{Ta} 1-\mathrm{S} 2=84.72(4), \mathrm{S} 1-\mathrm{Ta} 1-\mathrm{S} 3$ 168.01(5), S1-Ta1-Cl3 = 96.24(5), S1-Ta1-Cl2 = 105.79(5), $\mathrm{S} 1-\mathrm{Ta} 1-\mathrm{S} 2=91.23(4), \mathrm{S} 1-\mathrm{Ta} 1-\mathrm{Cl} 1=97.98(5), \mathrm{Cl} 2-\mathrm{Ta} 1-\mathrm{S} 3=84.83(5), \mathrm{Cl} 2-\mathrm{Ta} 1-\mathrm{Cl} 3=96.45(5)$, 
$\mathrm{Cl} 2-\mathrm{Ta} 1-\mathrm{S} 2=162.66(5), \mathrm{Cl} 2-\mathrm{Ta} 1-\mathrm{Cl} 1=96.37(5), \mathrm{S} 2-\mathrm{Ta} 1-\mathrm{S} 3=78.58(4), \mathrm{Cl} 1-\mathrm{Ta} 1-\mathrm{S} 3=86.10(4)$, $\mathrm{Cl} 1-\mathrm{Ta} 1-\mathrm{Cl} 3=157.48(5), \mathrm{Cl} 1-\mathrm{Ta} 1-\mathrm{S} 2=77.61(4)$;

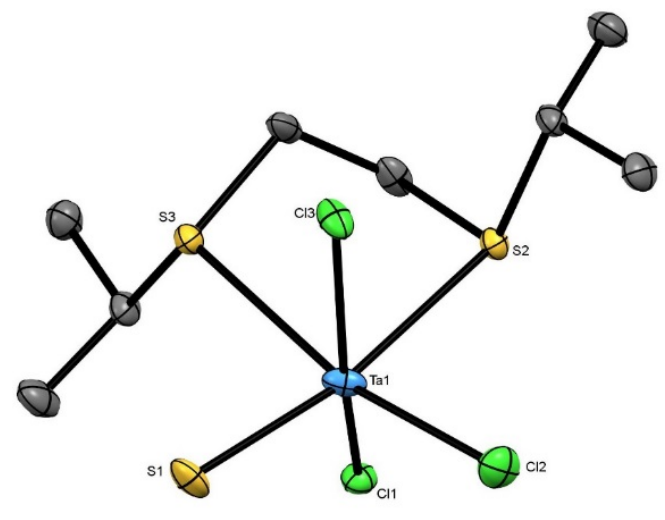

Figure 3 View of the structure of $\left[\mathrm{TaSCl}_{3}\left(\mathrm{PrSCH}_{2} \mathrm{CH}_{2} \mathrm{~S}\right.\right.$ Pr $\left.)\right]$ with numbering scheme adopted. Ellipsoids are shown at the $50 \%$ probability level and $\mathrm{H}$ atoms are omitted for clarity. Note that $\mathrm{S} 1$ and $\mathrm{Cl} 2$ are disordered Selected bond lengths $(\AA)$ and angles $\left({ }^{\circ}\right)$ : Ta1-Cl1 $=2.3509(4), \mathrm{Ta} 1-\mathrm{Cl} 3=$ 2.3559(5), $\mathrm{Ta} 1-\mathrm{Cl} 2=2.2442(5), \mathrm{Ta} 1-\mathrm{S} 2=2.7487(5), \mathrm{Ta} 1-\mathrm{S} 3=2.7375(5), \mathrm{Ta} 1-\mathrm{S} 1=2.2339(5)$, $\mathrm{Cl} 1-\mathrm{Ta} 1-\mathrm{Cl} 3=155.464(17), \mathrm{Cl} 1-\mathrm{Ta} 1-\mathrm{S} 2=76.447(15), \mathrm{Cl} 1-\mathrm{Ta} 1-\mathrm{S} 3=85.118(15), \mathrm{Cl} 3-\mathrm{Ta} 1-\mathrm{S} 2=$ 83.485(15), Cl3-Ta1-S3 = 77.214(15), Cl2-Ta1-Cl1 = 97.282(17), Cl2-Ta1-Cl3 = 96.615(18), $\mathrm{Cl} 2-\mathrm{Ta} 1-\mathrm{S} 2$ 89.812(17), Cl2-Ta1-S3 = 167.641(17), S3-Ta1-S2 = 78.929(14), S1-Ta1-Cl1 = 98.236(17), S1-Ta1-Cl3 = 97.905(18), S1-Ta1-Cl2 = 103.941(19), S1-Ta1-S2 = 165.867(16), S1-Ta1-S3 = 87.635(17).

The structure present in the dark purple crystals of $\left[\mathrm{TaSCl}_{3}\left(\mathrm{MeSeCH}_{2} \mathrm{CH}_{2} \mathrm{SeMe}\right)\right]$ (Figure 4) shows a similar geometry to the dithioether complexes, with $\mathrm{S} / \mathrm{Cl}$ disorder trans to the diselenoether.

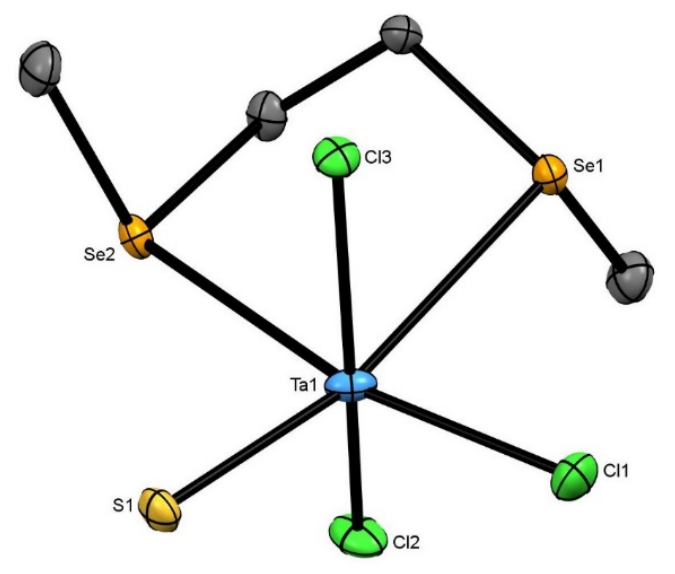

Figure 3 View of the structure of $\left[\mathrm{TaSCl}_{3}\left(\mathrm{MeSeCH}_{2} \mathrm{CH}_{2} \mathrm{SeMe}\right)\right]$ with numbering scheme adopted. Ellipsoids are shown at the $50 \%$ probability level and $\mathrm{H}$ atoms are omitted for clarity. Note that $\mathrm{S} 1$ and $\mathrm{Cl} 1$ are disordered Selected bond lengths $(\AA)$ and angles $\left({ }^{\circ}\right)$ : Ta1-Se1 = 2.8412(5), Ta1-Se2 = $2.8050(5), \mathrm{Ta} 1-\mathrm{Cl} 3=2.3592(11), \mathrm{Ta} 1-\mathrm{Cl} 1=2.2671(12), \mathrm{Ta} 1-\mathrm{Cl} 2=2.3543(12), \mathrm{Ta} 1-\mathrm{S} 1=$ 
2.2293(12), Se2-Ta1-Se1 = 80.046(14), Cl3-Ta1-Se1 = 76.31(3), Cl3-Ta1-Se2 = 85.05(3), $\mathrm{Cl} 1-\mathrm{Ta} 1-\mathrm{Se} 1=83.77(4), \mathrm{Cl} 1-\mathrm{Ta} 1-\mathrm{Se} 2=162.78(4), \mathrm{Cl} 1-\mathrm{Ta} 1-\mathrm{Cl} 3=96.85(5), \mathrm{Cl} 1-\mathrm{Ta} 1-\mathrm{Cl} 2=$ 96.26(5), Cl2-Ta1-Se1 = 86.58(3), Cl2-Ta1-Se2 = 77.01(3), Cl2-Ta1-Cl3 = 157.11(4), S1-Ta1-Se1 $=168.12(3), \mathrm{S} 1-\mathrm{Ta} 1-\mathrm{Se} 2=90.35(3), \mathrm{S} 1-\mathrm{Ta} 1-\mathrm{Cl} 3=96.05(4), \mathrm{S} 1-\mathrm{Ta} 1-\mathrm{Cl} 1=106.41(5), \mathrm{S} 1-\mathrm{Ta} 1-\mathrm{Cl} 2$ $=98.13(4)$.

The spectroscopic data are similar to those reported for the corresponding niobium systems [8]. In the IR spectra the $v(T a=S)$ is found as a medium intensity feature $\sim 505-510 \mathrm{~cm}^{-1}$, except for $\left[\mathrm{TaSCl}_{3}\left(\mathrm{PhSCH}_{2} \mathrm{CH}_{2} \mathrm{SPh}\right)\right]$ where there are two bands at $513,519 \mathrm{~cm}^{-1}$, neither corresponds to any dithioether ligand modes, and the splitting is presumably due to a solid state effect. Two bands were also noted for this complex in the original study [4]. The $v(\mathrm{Ta}-\mathrm{Cl})$ are assigned as (usually two) bands which lie in the range $305-360 \mathrm{~cm}^{-1}$. The ${ }^{1} \mathrm{H}$ NMR spectrum of $\left[\mathrm{TaSCl}_{3}\left(\mathrm{PhSCH}_{2} \mathrm{CH}_{2} \mathrm{SPh}\right)\right]$ in $\mathrm{CD}_{2} \mathrm{Cl}_{2}$ at $295 \mathrm{~K}$ shows a single $\delta\left(\mathrm{CH}_{2}\right)$ resonance indicating fast exchange, but on cooling the solution to $223 \mathrm{~K}$ two $\delta\left(\mathrm{CH}_{2}\right)$ resonances are present consistent with the expected structure, as the exchange slows. The ${ }^{1} \mathrm{H}$ NMR spectra of the dithioalkane complexes mostly show two RS- and two $\mathrm{SCH}_{2}$ (backbone) resonances at room temperature as broad singlets distinguishing the donor groups which are inequivalent in these structures, and consistent with stronger donation in the alkyl substituted ligands. Cooling of the solutions, further results in the reversible appearance of more complex resonance patterns, no doubt due to the slowing of pyramidal inversion at the coordinated sulfur, but these are too complex to assign and are not reported. The IR and ${ }^{1} \mathrm{H} N M R$ spectra of $\left[\mathrm{TaSCl}_{3}\left(\mathrm{MeSeCH}_{2} \mathrm{CH}_{2} \mathrm{SeMe}\right)\right]$, which contains a five-membered chelate ring, are broadly similar to those of the dithioether analogue and the ${ }^{77} \mathrm{Se}\left\{{ }^{1} \mathrm{H}\right\}$ NMR spectrum of the diselenahexane complex shows two $\delta(\mathrm{Se})$ resonances due to the selenium trans to $\mathrm{Cl}$ and $\mathrm{S}$. A small amount of $\mathrm{Me}_{2} \mathrm{Se}_{2}$ is also evident (266 ppm); this is most likely a result of some elimination of $-\mathrm{CH}_{2} \mathrm{CH}_{2}-$ from the ligand backbone in solution [23]. However the ${ }^{1} \mathrm{H}$ NMR spectrum of [ $\left.\mathrm{TaSCl}_{3}\left({ }^{n} \mathrm{BuSeCH}_{2} \mathrm{CH}_{2} \mathrm{CH}_{2} \mathrm{Se}^{n} \mathrm{Bu}\right)\right]$ is little different that of the free diselenoether, and the complex fails to exhibit a $\delta\left({ }^{77} \mathrm{Se}\right)$ resonance, which are consistent with extensive dissociation in the case of the larger (six-membered) chelate ring complex.

Complexes with $n$-butyl substituents were targeted as potential single source CVD reagents (below) since these can, in principle, undergo $\beta$-hydride elimination on heating. Unfortunately, the reaction of $\mathrm{TaCl}_{5}, \mathrm{~S}\left(\mathrm{SiMe}_{3}\right)_{2}$ and the monodentate ligands $\mathrm{S}^{n} \mathrm{Bu}_{2}$ or $\mathrm{Se}^{\mathrm{n}} \mathrm{Bu}_{2}$ in anhydrous $\mathrm{CH}_{2} \mathrm{Cl}_{2}$ solution, produced black powders with highly variable analytical composition, and these lacked any IR spectral evidence for a Ta=S feature. In solution the ${ }^{1} \mathrm{H}$ (and for the selenoether compound) 
the ${ }^{77}$ Se NMR spectra showed features only due the uncoordinated chalcogenoether, and the nature of these black products is unknown. In the niobium systems, $\left[\mathrm{NbSCl}_{3}\left(\mathrm{SR}_{2}\right)\right]\left(\mathrm{R}=\mathrm{Me},{ }^{\mathrm{n}} \mathrm{Bu}\right)$ and $\left[\mathrm{NbSCl}_{3}\left(\mathrm{Se}^{\mathrm{n}} \mathrm{Bu}_{2}\right)\right]$ were prepared and the structure of the $\mathrm{SMe}_{2}$ complex determined [8]. It is a dimer $\left[\mathrm{Nb}_{2} \mathrm{~S}_{2} \mathrm{Cl}_{4}(\mu-\mathrm{Cl})_{2}\left(\mathrm{SMe}_{2}\right)_{2}\right]$ with the sulphides terminal in plane and with syn axial $\mathrm{SMe}_{2}$ ligands. A red 2:1 complex $\left[\mathrm{TaSCl}_{3}\left(\mathrm{SMe}_{2}\right)_{2}\right]$ has been described, but with very limited characterisation [4].

Finally, attempts to deposit $\mathrm{TaE}_{2}$ thin films by low pressure CVD were carried out using the equipment described for the niobium analogues [8] (see Supporting Information) and [ $\left.\mathrm{TaSCl}_{3}\left({ }^{\mathrm{n}} \mathrm{BuSCH} \mathrm{CH}_{2} \mathrm{CH}_{2} \mathrm{~S}^{\mathrm{n}} \mathrm{Bu}\right)\right]$ and $\left[\mathrm{TaSCl}_{3}\left({ }^{\mathrm{n}} \mathrm{BuSeCH}_{2} \mathrm{CH}_{2} \mathrm{CH}_{2} \mathrm{Se}^{\mathrm{n}} \mathrm{Bu}\right)\right]$ as reagents. Unfortunately, the newly prepared thioether complex gave no deposit, while the selenoether reagent produced only red elemental selenium films (as demonstrated through grazing incidence $\mathrm{X}$-ray diffraction (GIXRD) and scanning electron microscopy (SEM) and energy dispersive X-ray (EDX) analysis, with no evidence for any $\mathrm{TaE}_{2}$ (see Supplementary Information).

\section{Conclusions}

The preparations and characterisation of a series of very unusual $\mathrm{Ta}(\mathrm{V})$ sulfide trichloride complexes with soft, neutral dithioether and diselenoether co-ligands is reported, including crystal structures of representative examples, all of which display distorted octahedral coordination with the bidentate ligand lying trans to $\mathrm{S} / \mathrm{Cl}$. Except where there is $\mathrm{S} / \mathrm{Cl}$ disorder evident in the crystal structures, the higher trans influence of the sulfide vs. chloride is clearly manifested in the Ta-S $S_{\text {thioether }}$ bond distances and the spectroscopic data are in accord with the solid state structures. The products obtained from similar reactions with the monodentate ligands $\mathrm{E}^{\mathrm{n} B \mathrm{~B}_{2}}(\mathrm{E}=\mathrm{S}$, Se) were irreproducible and could not be identified.

Investigation of the ${ }^{\mathrm{B}} \mathrm{Bu}$-bearing dithioether and diselenoether complexes as potential CVD precursors for tantalum sulfide/selenide thin film growth proved unsuccessful, the thioether regent yielding no deposit (contrasting with the corresponding niobium(V) complex, which gave $\mathrm{NbS}_{2}$ films), while the selenoether complex yielded only elemental selenium. Introducing tantalum in place of niobium has the obvious consequence of increasing the molecular weight of the corresponding complex by 88 a.m.u.. However, this is unlikely to be the major cause of the failure of the $\mathrm{Ta}(\mathrm{V})$ complexes to function as CVD reagents for $\mathrm{TaS}_{2}$, since, based upon the 
coordination chemistry, the $\mathrm{TaOCl}_{3}$ and $\mathrm{TaSCl}_{3}$ complexes generally appear to be significantly less stable than the niobium analogues, reflecting the harder Lewis acidity of $\mathrm{Ta}(\mathrm{V})[4,6,7,8,10]$.

\section{Acknowledgements}

We thank the EPSRC for support via EP/M50662X/1 and EP/N509747/1.

\section{Conflicts of interest}

The authors have no conflicts to declare.

\section{Appendix A. Supplementary Data.}

CCDC 1899988 [ $\left.\mathrm{TaSCl}_{3}\left(\mathrm{MeSeCH} \mathrm{CH}_{2} \mathrm{SeMe}\right)\right], \mathrm{CCDC} 1899989$ [ $\mathrm{TaSCl}_{3}\left({ }^{\mathrm{n}} \mathrm{BuSCH}_{2} \mathrm{CH}_{2} \mathrm{CH}_{2} \mathrm{~S}^{\mathrm{n}} \mathrm{Bu}\right)$ ], CCDC 1899990 [ $\left.\mathrm{TaSCl}_{3}\left({ }^{\mathrm{P} P S C H} \mathrm{CH}_{2} \mathrm{~S} \mathrm{Pr}\right)\right], \quad \mathrm{CCDC} 1899991 \quad\left[\mathrm{TaSCl}_{3}\left(\mathrm{MeSCH}_{2} \mathrm{CH}_{2} \mathrm{SMe}\right)\right]$ contain the supplementary crystallographic data for this paper. These data can be obtained free of charge via http://www.ccdc.cam.ac.uk/conts/retrieving.html, or from the Cambridge Crystallographic Data Centre, 12 Union Road, Cambridge CB2 1EZ UK. Other supplementary materials include IR and NMR spectra for the complexes. Details of the low pressure CVD experiments are also provided.

\section{References}

[1] L. G. Hubert-Pfalzgraf, M. Postel, J. G. Riess, in Comprehensive Coordination Chemistry, G. Wilkinson, R. D. Gillard, J. A. McCleverty (eds), Pergamon, Oxford 3 (1987) 585.

[2] T. Waters, A. G. Wedd, in Comprehensive Coordination Chemistry II, J. A. McCleverty, T. J. Meyer (eds), Elsevier, Amsterdam. 4 (2004) 241.

[3] D. A. Rice, Coord. Chem. Rev. 25 (1978) 199.

[4] M. G. B. Drew, D. A. Rice, D. M. Williams, J. Chem. Soc. Dalton Trans. (1984) 845.

[5] M. G. B. Drew, R. J. Hobson, Inorg. Chim. Acta 72 (1983) 233.

[6] K. Behzadi, A. G. Baghlaf, A. Thompson, J. Less Common Metals, 128 (1987) 195.

[7] M. G. B. Drew, D. A. Rice, D. M. Williams, J. Chem. Soc., Dalton Trans. (1983) 2251.

[8] Y.-P. Chang, A. L. Hector, W. Levason, G. Reid, Dalton Trans. 46 (2017) 9824.

[9] A. Noll, U. Müller, Z. Anorg. Allg. Chem. 625 (1999) 803.

[10] R. D. Bannister, W. Levason, M. E. Light, G. Reid, Polyhedron, in press.

[11] M. Chhowalla, Z. Liu and H. Zhang, (Eds. - themed issue on metal dichalcogenides) Chem. Soc. Rev., 2015, 44, 2584. 
[12] A. C. Jones and M. L. Hitchman, in Chemical Vapour Deposition: Precursors, Processes and Applications, ed. A. C. Jones and M. L. Hitchman, Royal Society of Chemistry, 2009.

[13] S. L. Benjamin, Y.-P. Chang, C. Gurnani, A. L. Hector, M. Huggon, W. Levason, G. Reid, Dalton Trans. 43 (2014) 16640.

[14] S. L. Benjamin, Y.-P. Chang, M. Huggon, W. Levason, G. Reid, Polyhedron 99 (2015) 230.

[15] Y.-P. Chang, W. Levason, M. E. Light, G. Reid, Dalton Trans. 45 (2016) 16262.

[16] F. R. Hartley, S. G. Murray, W. Levason, H. E. Soutter, C. A. McAuliffe, Inorg. Chim. Acta 35 (1979) 265.

[17] D. J. Gulliver, E. G. Hope, W. Levason, S. G. Murray, D. M. Potter, G. L. Marshall, J. Chem. Soc., Perkin Trans. II (1984) 429.

[18] C. Gurnani, S. L. Hawken, A. L. Hector, R. Huang, M. Jura, W. Levason, J. Perkins, G. Reid, G. B. G. Stenning, Dalton Trans. 47 (2018) 2628.

[19] C. H. de Groot, C. Gurnani, A. L. Hector, R. Huang, M. Jura, W. Levason, G. Reid, Chem. Mater. 24 (2012) 4442,

[20] G. M. Sheldrick, Acta Crystallogr. C71 (2015) 3.

[21] I. Nowak, E. M. Page, D. A. Rice, A. D. Richardson, R. J. French, K. Hedberg, J. S. Ogden, Inorg. Chem. 42 (2003) 1296.

[22] M. G. B. Drew, D. A. Rice, D. M. Williams, J. Chem. Soc., Dalton Trans. (1984) 1087.

[23] R. Hart, W. Levason, B. Patel, G. Reid, J. Chem. Soc., Dalton Trans. (2002) 3153. 
Table $1 \mathrm{X}$-ray crystallographic data ${ }^{\mathrm{a}}$

\begin{tabular}{|c|c|c|c|}
\hline Compound & {$\left[\mathrm{TaSCl}_{3}\left(\mathrm{MeSCH}_{2} \mathrm{CH}_{2} \mathrm{SMe}\right)\right]$} & {$\left[\mathrm{TaSCl}_{3}\left(\mathrm{MeSeCH}_{2} \mathrm{CH}_{2} \mathrm{SeMe}\right)\right]$} & {$\left[\mathrm{TaSCl}_{3}\left({ }^{(} \mathrm{PrSCH}{ }_{2} \mathrm{CH}_{2} \mathrm{~S}^{\mathrm{i}} \mathrm{Pr}\right)\right]$} \\
\hline Formula & $\mathrm{C}_{4} \mathrm{H}_{10} \mathrm{Cl}_{3} \mathrm{~S}_{3} \mathrm{Ta}$ & $\mathrm{C}_{4} \mathrm{H}_{10} \mathrm{Cl}_{3} \mathrm{SSe}_{2} \mathrm{Ta}$ & $\mathrm{C}_{8} \mathrm{H}_{18} \mathrm{Cl}_{3} \mathrm{~S}_{3} \mathrm{Ta}$ \\
\hline$M$ & 441.60 & 535.40 & 497.70 \\
\hline Crystal system & Monoclinic & Monoclinic & Monoclinic \\
\hline Space group (no.) & $\mathrm{P} 2{ }_{1}(4)$ & $\mathrm{P} 2{ }_{1}(4)$ & $\mathrm{P} 2{ }_{1} / \mathrm{c}(14)$ \\
\hline$a / \AA ̊$ & $7.22174(15)$ & $7.3780(3)$ & $8.7703(2)$ \\
\hline$b / \AA$ & $11.36725(15$ & $11.4853(4)$ & $9.1766(2)$ \\
\hline$c / \AA$ & $7.93897(16)$ & $8.0629(3)$ & $19.7147(4)$ \\
\hline$\alpha /{ }^{\circ}$ & 90 & 90 & 90 \\
\hline$\beta /{ }^{\circ}$ & $115.595(3)$ & $115.924(5)$ & $98.565(2)$ \\
\hline$\gamma /{ }^{\circ}$ & 90 & 90 & 90 \\
\hline$U / \AA^{3}$ & $587.77(2)$ & $614.49(5)$ & $1568.97(6)$ \\
\hline$Z$ & 2 & 2 & 4 \\
\hline$\mu\left(\mathrm{Mo}^{-\mathrm{K}_{\alpha}}\right) / \mathrm{mm}^{-1}$ & 10.508 & 15.635 & 7.886 \\
\hline$F(000)$ & 412 & 484 & 952 \\
\hline Total number reflns & 5355 & 12183 & 32686 \\
\hline$R_{\text {int }}$ & 0.018 & 0.030 & 0.023 \\
\hline Unique reflns & 2267 & 2412 & 3090 \\
\hline $\begin{array}{l}\text { No. of params, } \\
\text { restraints }\end{array}$ & 102,1 & 102,1 & 140,0 \\
\hline GOF & 1.069 & 1.036 & 1.071 \\
\hline$R_{1}, w R_{2}[I>2 \sigma(I)]^{b}$ & $0.015,0.034$ & $0.012,0.030$ & $0.011,0.026$ \\
\hline $\mathrm{R}_{1}, \mathrm{wR}_{2}$ (all data) & $0.015,0.034$ & $0.012,0.030$ & $0.013,0.026$ \\
\hline
\end{tabular}

${ }^{a}$ Common items: $T=293 \mathrm{~K}$; wavelength $\left(\right.$ Mo- $\left.K_{\alpha}\right)=0.71073 \AA ; \theta(\max )=27.5^{\circ} ;{ }^{b} \mathrm{R}_{1}=\Sigma|| \mathrm{Fo} \mid-$

$|\mathrm{Fc}||/ \Sigma| \mathrm{Fo} \mid ; \mathrm{wR}_{2}=\left[\Sigma \mathrm{w}\left(\mathrm{Fo}^{2}-\mathrm{Fc}^{2}\right)^{2} / \Sigma \mathrm{wFo}^{4}\right]^{1 / 2}$ 
Table 1 continued.

\begin{tabular}{|c|c|}
\hline Compound & {$\left[\mathrm{TaSCl}_{3}\left({ }^{\mathrm{n}} \mathrm{BuSCH}_{2} \mathrm{CH}_{2} \mathrm{CH}_{2} \mathrm{~S}^{\mathrm{n}} \mathrm{Bu}\right)\right]$} \\
\hline Formula & $\mathrm{C}_{11} \mathrm{H}_{24} \mathrm{Cl}_{3} \mathrm{~S}_{3} \mathrm{Ta}$ \\
\hline$M$ & 539.78 \\
\hline Crystal system & Tetragonal \\
\hline Space group (no.) & $P 41(76)$ \\
\hline$a / \AA ̊$ & $9.65170(10)$ \\
\hline$b / \AA$ & $9.65170(10)$ \\
\hline$c / \AA$ & $19.9311(3)$ \\
\hline$\alpha /{ }^{\circ}$ & 90 \\
\hline$\beta / /^{\circ}$ & 90 \\
\hline$\gamma /{ }^{\circ}$ & 90 \\
\hline$U / \AA^{3}$ & $1856.69(5)$ \\
\hline$Z$ & 4 \\
\hline$\mu\left(\mathrm{Mo}^{\left.-\mathrm{K}_{\alpha}\right)} / \mathrm{mm}^{-1}\right.$ & 6.672 \\
\hline$F(000)$ & 1048 \\
\hline Total number reflns & 40170 \\
\hline$R_{\text {int }}$ & 0.071 \\
\hline Unique reflns & 3642 \\
\hline $\begin{array}{l}\text { No. of params, } \\
\text { restraints }\end{array}$ & 165,1 \\
\hline GOF & 1.068 \\
\hline$R_{1}, w_{2}[I>2 \sigma(I)]^{b}$ & $0.027,0.064$ \\
\hline $\mathrm{R}_{1}, \mathrm{wR}_{2}$ (all data) & $0.029,0.065$ \\
\hline
\end{tabular}

